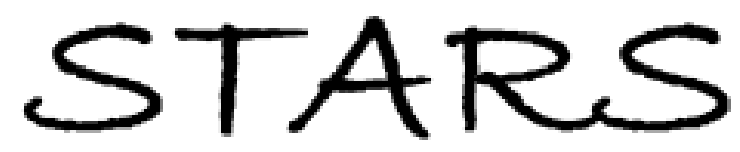

University of Central Florida

STARS

$1-1-2014$

\title{
Death And Disability In A Younge Phase Community
}

Michael W. Spence

Lana J. Williams

University of Central Florida

Sandra M. Wheeler

University of Central Florida

Find similar works at: https://stars.library.ucf.edu/facultybib2010 University of Central Florida Libraries http://library.ucf.edu

This Article is brought to you for free and open access by the Faculty Bibliography at STARS. It has been accepted for inclusion in Faculty Bibliography 2010s by an authorized administrator of STARS. For more information, please contactSTARS@ucf.edu.

\section{Recommended Citation}

Spence, Michael W.; Williams, Lana J.; and Wheeler, Sandra M., "Death And Disability In A Younge Phase Community" (2014). Faculty Bibliography 2010s. 6119.

https://stars.library.ucf.edu/facultybib2010/6119

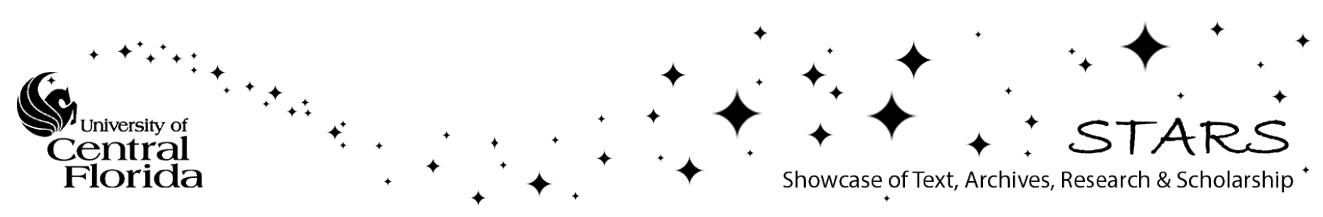




\title{
DEATH AND DISABILITY IN A YOUNGE PHASE COMMUNITY
}

\author{
Michael W. Spence, Lana J. Williams, and Sandra M. Wheeler
}

\begin{abstract}
Roffelsen is an early Younge phase mortuary component in southwestern Ontario. The single burial feature is a pit containing the articulated skeletons of seven successively buried individuals, ranging in age from a few months to late middle age. All had been stripped of soft tissues, except for the connecting tissues that maintained their articulation. Most also had a disk cut from the cranium and a hole drilled near bregma. All but the infant display various forms of developmental failure of the outer and middle ear and the petrous portion of the temporal bone. The pit was apparently the burial facility for an extended family with significant hearing impairments. This disability may have limited their interaction with neighboring communities, perhaps even playing a role in their eventual disappearance as a separate community.
\end{abstract}

Roffelsen est un site mortuaire dans le sud-ouest de l'Ontario datant du début de la phase Younge de la Tradition Western Basin, soit de 900 à 1200 après Jésus-Christ. L'unique tombe de ce site est une fosse contenant les squelettes articulés de sept individus dont l'âge varie de l'enfance à l'àge adulte. Ces individus ont été enterrés successivement plutôt que tous en même temps. Avant l'enterrement, chacun d'entre eux avaient été dépouillés de leurs tissus mous, sauf pour les tissus conjonctifs qui avaient tenu leurs os ensemble. Dans la plupart des cas, un disque avait aussi été coupé du crâne et un trou avait été percé dans ce dernier, près du bregma. Tous, sauf le nourrisson, démontrent différentes formes de malformation au niveau du développement de l'oreille externe et celle moyenne et dans la partie pétreuse de l'os temporal. Ces malformations auraient probablement causé une perte auditive moyenne. Une analyse non métrique de traits indique que ces individus étaient de la mêtne famille. La fosse était évidemment le lieu d'enterrement d'une famille élargie ayant une déficience auditive importante. Ce handicap peut avoir limité leurs interactions avec les communautés voisines et peut également avoir joué un rôle dans leur disparition éventuelle en tant que communauté à part.

$\mathrm{A}$ s Speal (2006) has pointed out, much of the research on the Younge phase (A.D. 900-1200) of the Western Basin tradition has been devoted to securing archaeological basics like chronology, subsistence, and the ceramic sequence. For example, recent isotopic analyses have established that the Ontario Younge phase people were as fully reliant on maize horticulture as contemporary and even later Ontario Iroquoian tradition populations to the east (Dewar et al. 2010; Spence et al. 2010; Watts et al. 2011). However, there has been less done on social organization and ritual, and our understanding of these topics has come largely from burials in Michigan and Ohio, with some scattered examples from southwestern Ontario (Murphy and Ferris 1990). Younge phase burials show a bewildering variety of practices, including primary and secondary burial, rearticulation, flexed and extended positions, cremation, perforations of long bones and crania, disk removal, and the application of clay to facial areas (Fitting 1965:3-97; Greenman 1937; Raemsch 1993; Speal 2006). To further complicate matters, some of the major mortuary components encompass considerable temporal variability, making it difficult to tease out particular social expressions (Speal 2006). We should, then, be excavating more sites of limited temporal scope. This approach should also include the bioarchaeological analysis of burial components, focused on the contextual and osteological data that reveal social structure (Stojanowski and Schillaci 2006). A detailed analysis of mortuary procedures is needed to determine precisely what sort of treatment was ac-

\footnotetext{
Michael W. Spence a Department of Anthropology, University of Western Ontario, London, Ontario, Canada N5X 4R3 (spence@uwo.ca)

Lana J. Williams and Sandra M. Wheeler $\square$ Department of Anthropology, University of Central Florida, Orlando, FL 32816
} 


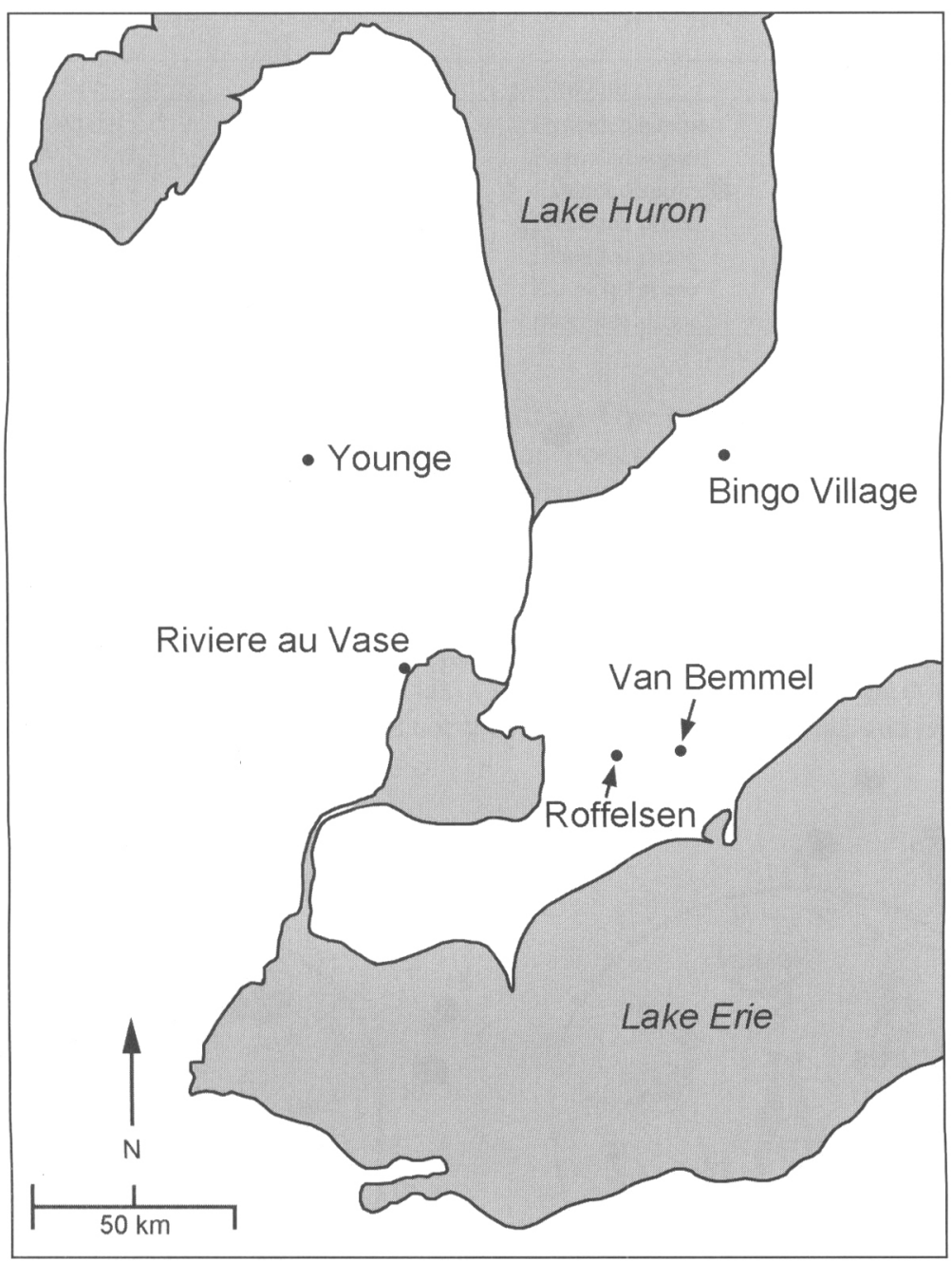

Figure 1. Selected Younge phase sites of southeastern Michigan and southwestern Ontario.

corded to what sort of person. Nonmetric trait distributions among the burials may allow inferences about relationships among the people, providing further insight into the social contexts of mortuary practice.

\section{The Roffelsen Site}

The Roffelsen site (AcHn-33) of southwestern Ontario, on the Thames River near Chatham, is an example of this sort of approach (Figure 1). It was fully excavated by the consulting firm of Archaeologix, and the material culture was analyzed by Adria Grant (Archaeologix Inc. 2006). The burial feature was excavated by Spence with as- sistance from Grant and Tracie Carmichael and with the consent of the Bkejwanng First Nation of Walpole Island. A detailed analysis of the skeletons is presented in Spence et al. (2007).

The site as a whole covered an area $50 \mathrm{~m}$ north-south by $45 \mathrm{~m}$ east-west (Figure 2). Much of it was encompassed within a single-row palisade $25 \mathrm{~m}$ in diameter. Thirteen pits were inside the palisade, while the rest, including all the hearths, were situated outside the palisade. No residential structures were present. The ceramics indicate use early in the Younge phase, ca. A.D. 900-1000 (Archaeologix 2006). The site was apparently a specialized mortuary component with only brief occupations. 


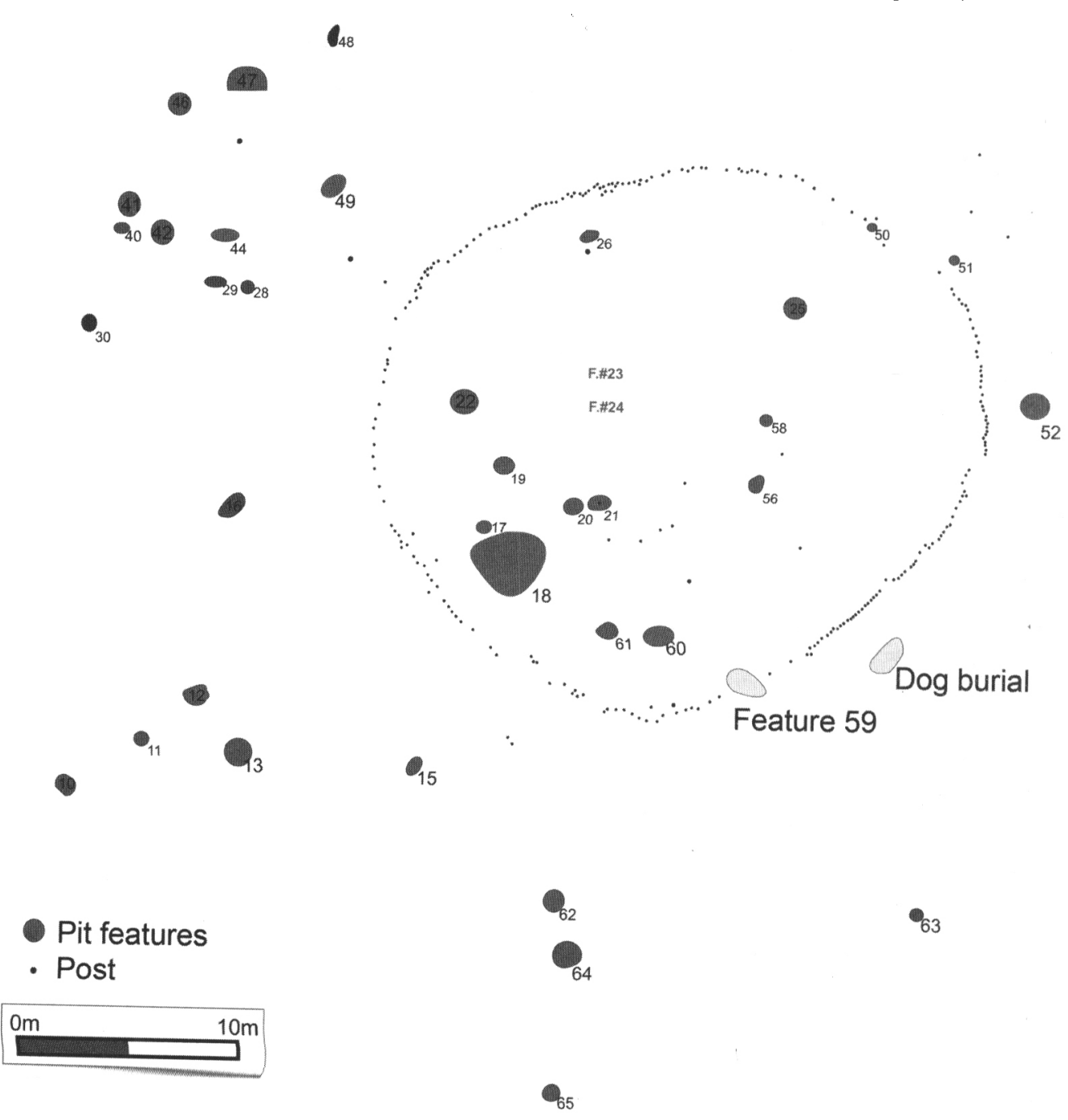

Figure 2. Roffelsen site plan, from plan by Adria Grant.

On the southeast edge of the enclosure there is a gap of about two meters, largely filled by Feature 59 , a multiple burial pit. Just outside the palisade is Feature 54, a dog burial (Figure 2).

\section{The Structure of Feature 59}

Feature 59 is an oval pit, 190 by $102 \mathrm{~cm}$, with its long axis oriented northwest-southeast. Although the original depth cannot be determined, the pit base lies $35 \mathrm{~cm}$ below the subsoil surface.

The feature contained the skeletal remains of seven individuals, designated A through $\mathrm{G}$ (Table 1; Figure 3). In the earlier stage of site excavation, Feature 59 was briefly probed, causing some dis- turbance of the burials. Much of $\mathrm{E}$ and the lower legs of $F$ were displaced, but were recovered. Another recent intrusion on the west side of the burial displaced some elements of $B$ and $C$. The pit fill was not stratified. None of the human bones showed evidence of animal interference.

The palisade posts did not continue through Feature 59, so the pit occupied a gap in the palisade rather than being a prior feature or later intrusion. Three posts were directly associated with the feature (Figure $3 \mathrm{~b}$ ). Two small posts, $3-4 \mathrm{~cm}$ in diameter, were near each other in the pit and visible only in its base, but the displacement of some overlying elements of $\mathrm{F}$ indicate that they had been put there after $F$ had undergone some de- 
Table 1. Sex, Age, Position, and Orientation of Individuals from the Roffelsen Site.

\begin{tabular}{lllll}
\hline Individual & Sex & Age & Position & Orientation \\
\hline A & Male & $50-70$ years & Extended supine & Head to northwest \\
B & - & $6-8$ years & Extended supine & Head to northwest \\
C & - & $3-4$ years & Extended supine & Head to southeast \\
D & - & $1.5-1.8$ years & Extended prone & Head to southeast \\
E & - & $1.5-1.8$ years & Extended prone & Head to northwest \\
F & Male & $18-19$ years & Extended prone & Head to northwest \\
G & - & $0-2$ months & Extended prone & Head to southeast \\
\hline
\end{tabular}

composition. A larger post, $10 \mathrm{~cm}$ in diameter, had been placed just beyond the northwest edge of the feature.

The seven individuals had been placed sequentially in the pit as articulated skeletons rather than as fully fleshed bodies (Figure 3). Numerous cutmarks indicate that most of the soft tissue had been removed, leaving only enough to maintain their articulation. The sequence of deposition (which is not indicated by their letter designations) is unclear at some points. Sex identification of $A$ and $F$ (Table 1) was based on pelvic criteria (Phenice 1969). The age of $\mathrm{A}$ is indicated by the stage VI morphology of the symphysis pubis, assigned an age of $61.2 \pm$ 12.2 years (Suchey and Katz 1998). For the subadults, long bone dimensions and dental formation provided the primary age criteria (Moorrees et al. 1963a, 1963b; Scheuer and Black 2000). In-
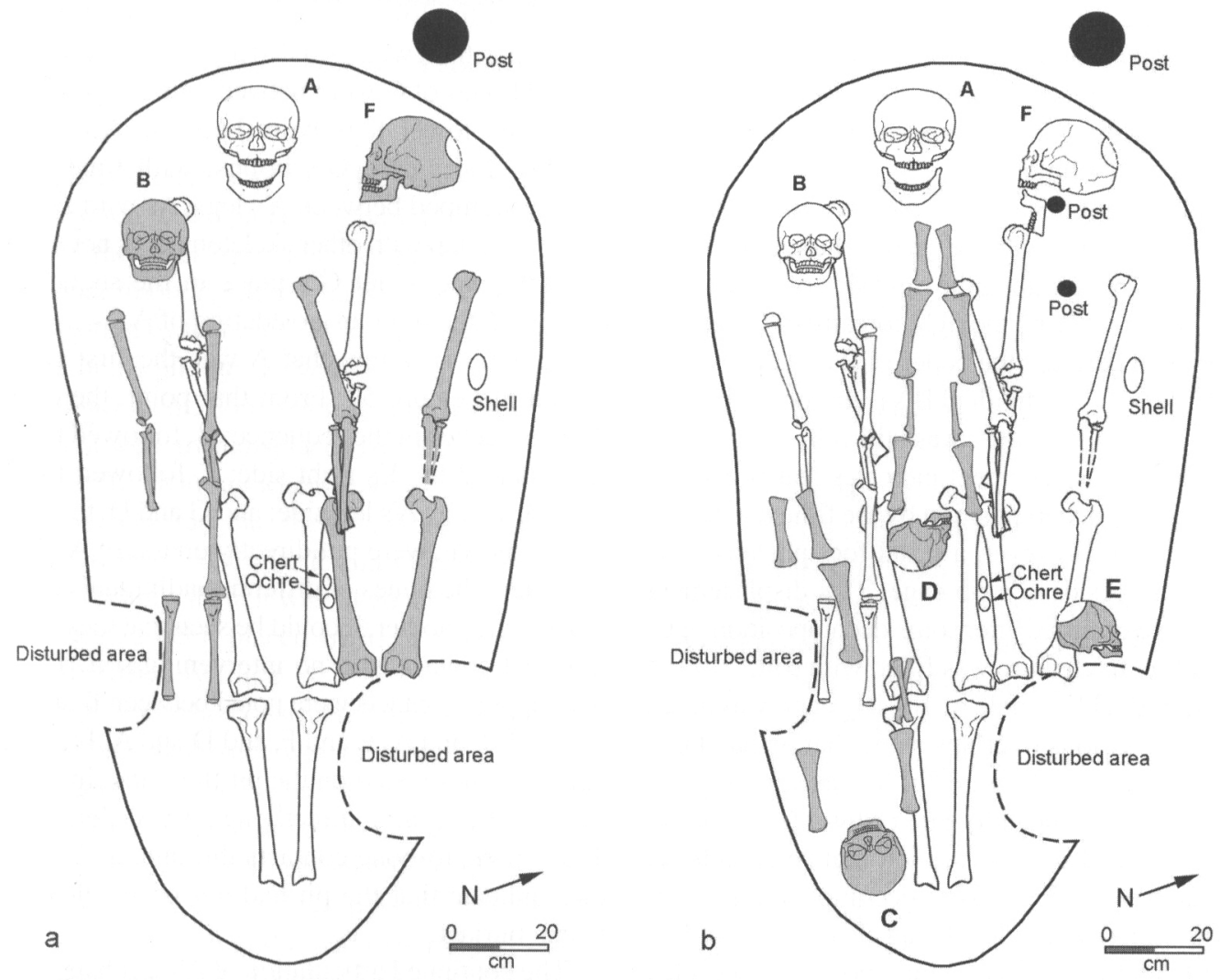

Figure 3. Feature 59 burial plan: (a) earliest burial $A$ in white, later $B$ and $F$ additions in gray; (b) earlier burials $A$, B, $\mathrm{F}$ in white, later additions $\mathrm{C}, \mathrm{D}, \mathrm{E}$ in gray. Burial $\mathrm{G}$ is not shown. Only crania, mandibles, and selected long bones are depicted. 
dividual $\mathrm{F}$ was aged largely by epiphyseal fusion (Scheuer and Black 2000).

The first individual to be placed in the pit was A, an adult male of about 50-70 years (Table 1). He was dorsally extended (supine), lying along the central axis of the pit, head to the northwest. His left hand rested by his side, his right hand on his thigh. Two of his maxillary teeth had fallen down among the cervical vertebrae, indicating decomposition before the pit became filled with soil.

After individual A, the sequence becomes uncertain as further individuals were placed to either side and on top of A. Individual B was placed to A's right, while $\mathrm{F}$ was placed to his left. There is no overlap between B and F, but the displacement of some of A's bones during the interment of $F$, but not that of $B$, suggests that $B$ may have preceded $F$.

Individual $B$, a child of 6-8 years, was in the supine extended position at A's right side, head to the northwest. Individual B's head and upper body rested on A's right shoulder and upper arm, with no intervening soil. The left hand of B rested on A's right carpals and metacarpals. None of A's bones had been displaced during the placement of $B$, suggesting that A's decomposition was not far advanced at that time.

Individual C, 3-4 years old, was in the supine extended position with the head to the southeast. Individual $C$ rested along the right side of $A$, with the lower legs overlying the right forearm of $B$. No soil intervened between the bones of $\mathrm{B}$ and the overlying bones of C. Individual B's right foot, lying beneath C's left humerus, was still fully articulated. The lack of displacement indicates that $\mathrm{B}$ had not suffered any decomposition by the time that $C$ was put in place. However, a distal foot phalanx of $\mathrm{C}$ was lying beside C's rib cage. This displacement must have occurred after some decomposition of $\mathrm{C}$, but before the feature was filled with soil.

Individual F, a male of 18-19 years, was at A's left side. Various overlaps show that he had been deposited after A (Figure 3a). F was ventrally extended (prone), head to the northwest. The burial of F displaced some of A's left hand elements, so A must have suffered some decomposition before $F$ was buried. Individual $F$ had also been disturbed after his burial. The two small posts had intruded on his skeleton, displacing his mandible and some vertebrae. In addition, some hand elements were displaced during E's burial.
Individual E, 1.5-1.8 years, had been placed in the grave after $F$. The cranium rested on F's right femur. No soil intervened, but an artifact of nonhuman bone was between E's cranium and F's right femur. Individual $\mathrm{E}$ had been disturbed during the initial testing of Feature 59, but parts of the cranium and mandible were still in situ. The location of several elements indicates that $E$ had been deposited in the ventrally extended position, head to the northwest, on F's legs.

Individual D, also 1.5-1.8 years, rested in the ventral extended position on top of $A$, with the head to the southeast (Figure 3b). Individual D's cranium was on A's pelvic girdle, the feet just beneath A's mandible. There was no soil between the bones of D and A. In fact, some of D's right ribs had fallen into the gap between A's sacrum and right innominate. This could not have occurred if A had been covered with soil after placement in the pit.

Individual G, only $0-2$ months old, had been placed on the lower legs of $A$ in the ventral extended position, with the head to the southeast. The cranial bones of $\mathrm{G}$ were between A's distal tibiae, while the lower legs were between A's distal femora. Individual G's bones, with time, had largely slumped between A's legs. As with D, the lack of overlap with other skeletons does not allow any inference about G's place in the sequence, other than the obvious postdating of A.

In sum, we know that $A$ was the first to be placed in Feature 59. From that point, there are three branches in the sequence: $\mathrm{B}$, followed by $\mathrm{C}$, were placed by A's right side; F, followed by $\mathrm{E}$, were placed by A's left side; and $G$ and $D$, their order unknown, were put directly on top of A.

Where the bones of different individuals overlapped one another, it could be seen that they were in direct contact with no intervening soil. These overlapping contacts were noted between $B$ and $A$, $\mathrm{C}$ and $\mathrm{B}, \mathrm{F}$ and $\mathrm{A}, \mathrm{E}$ and $\mathrm{F}$, and $\mathrm{D}$ and $\mathrm{A}$. Individual G's bones rested on the pit floor and, in some cases, were leaning directly against A's left tibia. These bone-to-bone contacts throughout the feature indicate that the pit had not been filled between burials.

The continued articulation of A's left hand during the placement of B, and of B's right foot when $C$ was put on top of it, suggests that these three were deposited in the feature in fairly short order, 

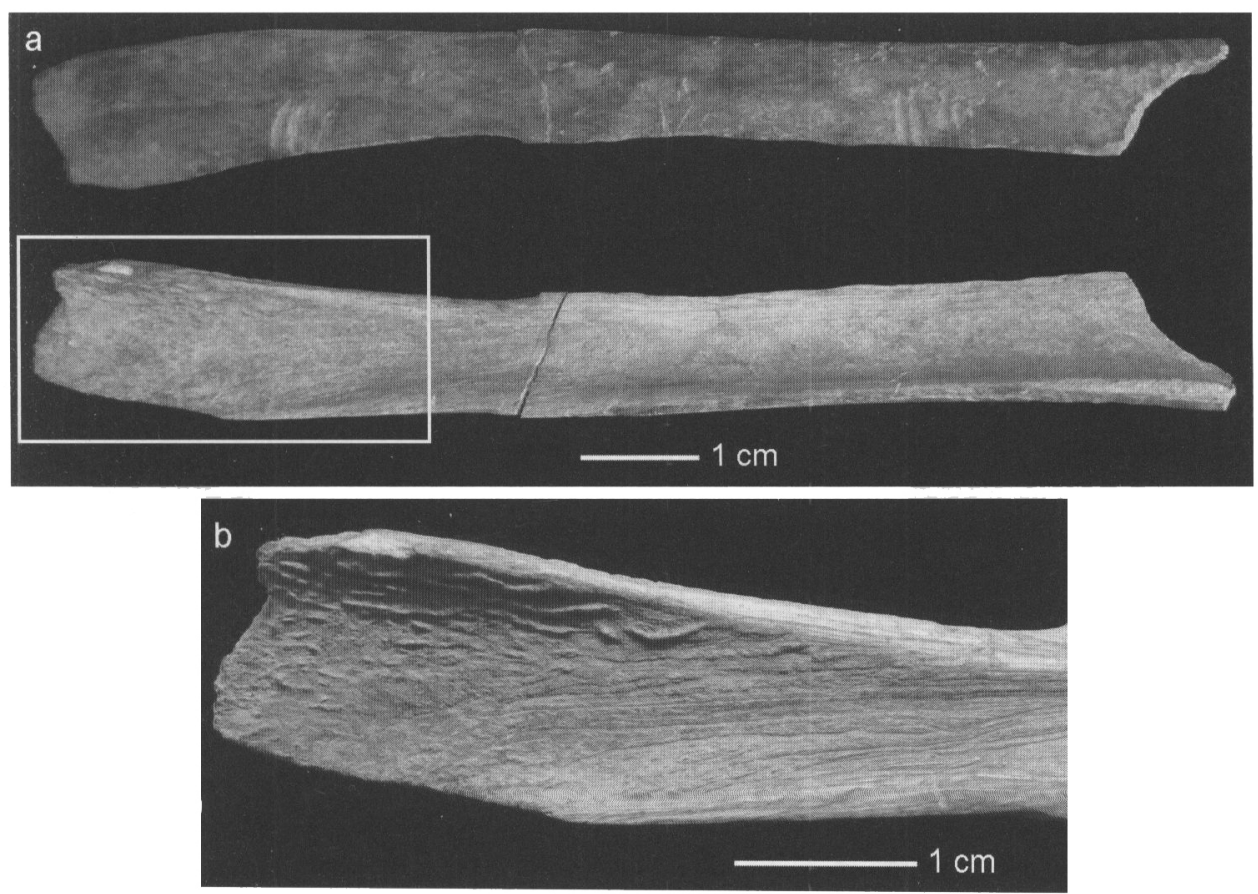

Figure 4. Bone tool in Feature 59: (a) interior and exterior; (b) detail of interior.

each before there was time for any serious decomposition of the preceding burial. The addition of F, on the other hand, displaced elements of A's left hand, implying that $A$ had suffered some decomposition by that time. This suggests that $F$ was placed in the pit after $\mathbf{B}$, whose burial had caused no displacement. Some elements of F's left hand and wrist were then displaced by E's burial.

It is difficult to say when Feature 59 was finally filled. We can say that there had been some decomposition of A, C, D, F and G before it was filled. Probably, then, it was filled after the last individual had been placed in it, or was, in fact, never deliberately filled.

The people who constructed and used Feature 59 must have had some way of protecting it from scavengers. The large post by the north edge of Feature 59 may have served to anchor a cover or superstructure of some perishable material, perhaps wood. The two smaller posts inside the pit, placed there after $A$ and $F$ had experienced some decomposition, may have been part of a termination ritual marking the end of the feature's use, or may have helped to secure the cover after it had experienced some deterioration.

\section{Grave Inclusions}

Only four items were found in Feature 59 (Figure 3). Half of a freshwater bivalve rested near the northeast side of the pit a few centimeters from F's right humerus. A lump of yellow ochre, $45 \mathrm{~mm}$ in diameter, and a chert flake were together just southeast of A's and F's left hands, which were lying closely together. The flake, of Onondaga chert, is 26 by 23 by $6 \mathrm{~mm}$. Cortex along one side indicates that it had been knocked off a source-area piece. There is some use-chipping on one edge.

A tool fashioned from the humerus of a swan or goose rested between the cranium of $E$ and the underlying right femur of $F$ (Figure 4). It shows some rodent gnawing and had been broken transversely in half. The break had occurred before the tool was deposited in Feature 59; the two halves were side-by-side rather than aligned. The tool, 107 by $14 \mathrm{~mm}$, had been manufactured by splitting the humerus lengthwise, then rounding off its long edges by longitudinal shaving and smoothing. One end shows no modification, while the other has use-smoothing. The two long edges have been smoothed and polished by use against a soft sub- 


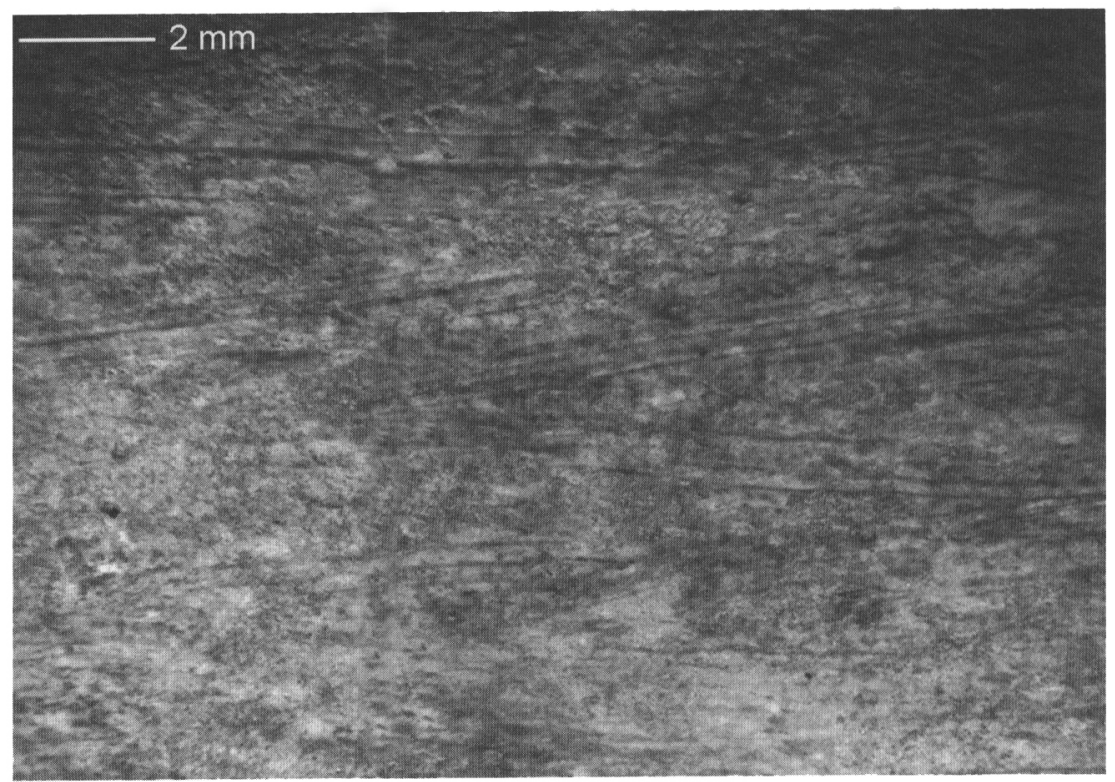

Figure 5. Cutting and scraping marks on shaft of individual A's fibula (10x).

stance. A very similar implement was found in a secondary burial at Bingo Village, another Younge phase Ontario component (Spence 2011).

\section{Mortuary Processing}

\section{Soft Tissue Removal}

The crania were removed intact to allow less hurried excavation in the laboratory. All bone surfaces were examined under magnification to document the extensive mortuary processing. The soft tissues had been almost entirely removed from the skeletal frame before burial. Additional modifications include drilled holes near bregma, the excision of cranial disks, and lacing holes on some long bones and vertebrae (see also Greenman 1937:27-58, 97; Redmond 1982; Speal 2006). Detailed descriptions for each individual are presented in Spence et al. (2007).

All of the observable long bones have cutting and scraping marks. Extensive scraping is indicated by closely spaced striations, which generally follow the long axis of the shaft (Figure 5). Cutmarks, on the other hand, are more common near or on the metaphyses and are more likely to be diagonal or perpendicular to the long axis. They are very rarely found on the epiphyses and at muscle and tendon attachment sites. The objective was apparently to remove virtually all of the soft tissue, even scouring it from between the adjacent surfaces of the radius and ulna and the tibia and fibula. However, soft tissues that were essential to articulation were left intact. Cuts are frequent on the metacarpals and metatarsals but very rarely found on the carpals, tarsals, and phalanges.

The patellae are missing from all individuals, apparently removed as part of the defleshing of the legs. During the defleshing of the arms of A and $F$, the medial epicondyles of the humeri, and part of the trochlear notch of A's right ulna, were cut off. Neither these nor the patellae were found on the site.

There are cutmarks on the exterior surfaces of many ribs, and occasionally on the pleural surfaces. On the innominates, they appear on both the internal and external surfaces, but not around the acetabulum. Most of the clavicles have cutmarks. Cutting and scraping marks on the scapulae are usually on the posterior surface, but sometimes on the anterior surface, particularly along its lateral margin. Much of the acromion processes of $A$ and $F$ had been cut off. The sternum and manubrium were missing from all individuals, probably removed to allow access to the internal organs. The spines of all of A's and F's vertebrae had been cut 


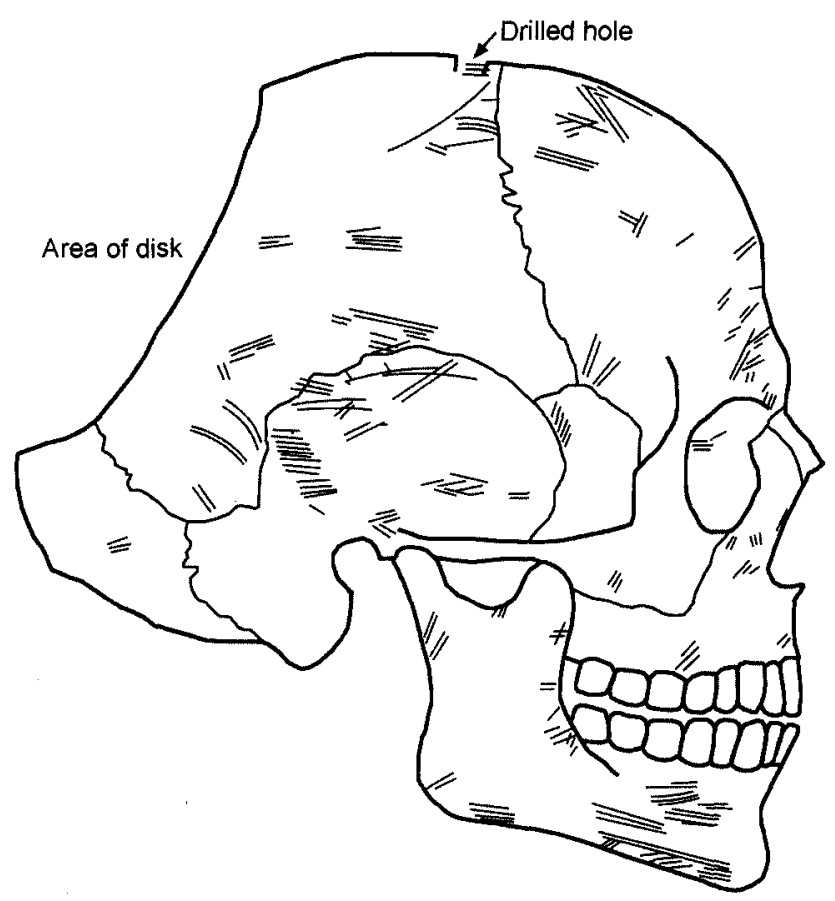

Figure 6. Cutting and scraping marks on cranium and mandible of individual F, right profile. The cuts and scoring along the perimeter of the disk opening are not shown.

off. Deep cuts occur on the bodies of a few vertebrae of A and C and on the anterior surface of F's sacrum, presumably inflicted during the removal of flesh and organs from the torso. The missing acromion processes, manubria, sterna, and vertebral spines were not present elsewhere in the site.

There are cutting and scraping marks on both the interior and exterior surfaces of the mandibles (Figure 6). In A and F, some are located around the mental spines and digastric fossae, indicating removal of the tongue. There are numerous cuts in the facial areas, including some within the orbital cavities of A-D and F (Figure 6). Cuts also occur at the nasal margins and across the nasal bones of A and F, suggesting the removal of the fleshy part of the nose. Some of the cuts on the temporal bones of $\mathrm{A}, \mathrm{D}$, and $\mathrm{F}$ are in locations where the fleshy external ears (pinna) would have been. All of the calvarial bones show some cutting or scraping marks. However, only $F$ has cutmarks on the cranial interior, indicating removal of the brain. A set of cuts crosses the superior surface of the right petrous element, and others occur on both sides of the left anterior clinoid process.
The infant $G$ has not been included in the descriptions above because, as the youngest and most poorly preserved of the seven individuals, most observations are impossible. However, there is evidence of some mortuary processing. There are transverse cuts on the left humerus shaft and scraping on a fragment of left femur or tibia.

Individual $\mathrm{G}$ suffered infantile cortical hyperostosis, also known as Caffey's disease (Ortner and Putschar 1985:294). There is newly deposited woven bone, not well integrated, overlying much of the established cortical bone on the shafts of the observable long bones: left humerus and ulna, both femora, right tibia, and left fibula (Figure 7). An alternative diagnosis of infantile scurvy is unlikely; there is no abnormal porosity of cranial elements or of the mandible (Brickley and Ives 2006).

Infantile cortical hyperostosis is not a disease or reaction to infection, but seems rather to be a developmental anomaly affecting some infants in the first year of life (Ortner and Putschar 1985:294; Scheuer and Black 2000:24). It may be due to the periosteum not being well bound to the cortical surface. Although not often fatal, it may 


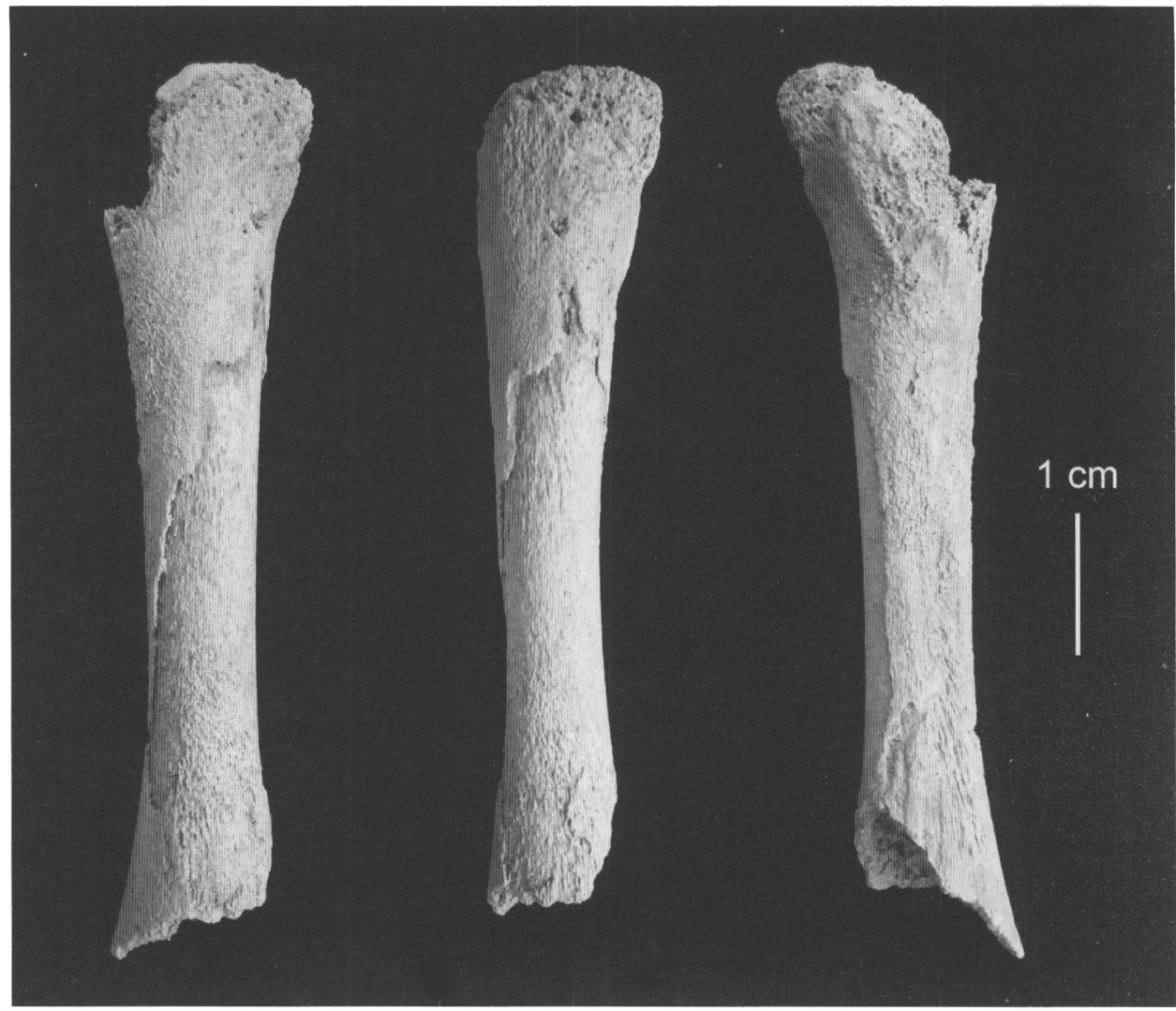

Figure 7. Right femur of individual G showing infantile cortical hyperostosis. Left to right: anterior; medial; and posterior views.

have been implicated in G's death. It may also have obscured more extensive evidence of mortuary processing. Cutmarks are not as visible on woven bone, and mortuary scraping may have removed segments of the poorly integrated layer.

\section{Rearticulation Efforts}

The attempt by the person doing the mortuary processing to produce an articulated skeleton was not always successful. As in other Younge phase sites (Greenman 1937), repairs were sometimes required. Lacing holes, usually $4-8 \mathrm{~mm}$ in diameter, were created during repair so that articulating bones could be tied together. The holes were probably made with something like a bone awl, not a drill.

The left humerus of A has one hole through the proximal metaphysis and another through the distal metaphysis. The left ulna has a hole entering on the medial side of the olecranon process and exiting on the anterior surface. This would have al- lowed attachment to the distal humerus. There are cuts across the posterior surface of the olecranon process that would have severed the tendon of Triceps brachii, weakening articulation at the elbow.

A large hole, 13 by $8 \mathrm{~mm}$, enters the distal metaphysis of F's right femur and extends proximally as a channel into the bone for $55 \mathrm{~mm}$. There is no exit. The hole could not have been made while the distal epiphysis was in position. Unfortunately the initial archaeological testing of Feature 59 displaced and damaged the unfused distal epiphysis and the articulating right tibia, so the purpose of the hole remains unclear.

Both $\mathrm{A}$ and $\mathrm{F}$ have lacing holes in their second and third lumbar vertebrae, apparently a weak spot in the articulated skeletons of these larger individuals. The holes in both second lumbars and in A's third lumbar all enter at the same point, the anterior right side of the body, near its inferior edge. The hole in F's third lumbar enters the right pedicle and exits on the posterior surface of the body. 
Table 2. Temporal Bone Maldevelopment of Individuals from the Roffelsen Site.

\begin{tabular}{|c|c|c|c|c|c|c|}
\hline & & & Individual & & & \\
\hline Element and condition & A & $\mathrm{B}$ & $\mathrm{C}$ & $\mathrm{D}$ & $\mathrm{E}$ & $\mathrm{F}$ \\
\hline Tympanic plate & UL, UR & PL, PR & UL,UR & $\mathrm{AL}, \mathrm{AR}$ & UL & UL,UR \\
\hline Stapes & $\mathrm{AL}, \mathrm{AR}$ & AL, UR & $\mathrm{AL}, \mathrm{PR}$ & & $\mathrm{AL}$ & $\mathrm{PL}, \mathrm{AR}$ \\
\hline Incus & PL, PR & $\mathrm{PL}, \mathrm{AR}$ & $\mathrm{AL}, \mathrm{PR}$ & & $\mathrm{AL}$ & PL, PR \\
\hline Malleus & PL, UR & $\mathrm{PL}, \mathrm{AR}$ & AL, PR & & $\mathrm{AL}$ & PL, PR \\
\hline Calcified tympanic membrane & $\mathrm{AL}, \mathrm{AR}$ & AL, PR & $\mathrm{AL}, \mathrm{AR}$ & $\mathrm{AL}, \mathrm{AR}$ & $\mathrm{AL}$ & $\mathrm{AL}, \mathrm{AR}$ \\
\hline Exposed carotid canal & AL, AR & $\mathrm{AL}, \mathrm{AR}$ & PL, AR & PL, PR & PL & PL, PR \\
\hline
\end{tabular}

$P=$ present $A=$ absent $;=$ underdeveloped; $L=$ left $R=$ right.

It is not clear how successful the attempt at repair was in F's case because the vertebrae are poorly preserved. Also, the bodies of lumbars 1-3 are riddled with osteolytic lesions, although they had not collapsed. The arches were not affected, and there is no sign of infection in lumbars 4-5 or the thoracic vertebrae. Individual F probably suffered from vertebral tuberculosis, which starts in childhood and most commonly affects the lumbar vertebrae (Ortner and Putschar 1985:145-149). Tuberculosis has been identified in a number of Ontario Iroquoian ossuary populations (Braun et al. 1998; Pfeiffer and Fairgrieve 1994:52-53) and may have played a role in F's early death.

\section{Cranial Perforations and Disks}

The crania of A, C, D, and F have small holes (7-12 $\mathrm{mm}$ in diameter) drilled through the bone near bregma (Figure 6). On $A$ and $F$ they are centered on the sagittal suture, while D's perforation is on the frontal bone, slightly anterior to bregma and lateral to the midline. Individual C's perforation would also have been on the sagittal suture, had the suture existed. $\mathrm{C}$ had premature sagittal synostosis, the very early fusion of the suture (David et al. 1982:127-128). Thus the parietal bone in $\mathrm{C}$ is one continuous bone rather than two separate elements. There are no perforations on $\mathrm{B}$ and $\mathrm{E}$, and no observation is possible for $\mathrm{G}$.

All but $\mathrm{G}$ (again unobservable) had disks removed from the cranial apex, posterior to the drilled holes and centered on lambda (Figure 6). These were large, ovaloid in shape, and removed the postero-medial parts of both parietals and the superior part of the occipital squama. Their excision involved cutting into the bone with a sharpedged tool and then scoring it deeply with something like a graver. The disk was finally freed from the surrounding bone by pressure or percussion, leaving the edge of the inner table somewhat irregular rather than cleanly cut.

Analysis of all material from the fully excavated site produced none of the missing elements: patellae, manubria, sterna, medial epicondyles, acromion processes, vertebral spines, and cranial disks. Either mortuary processing of the bodies was done somewhere else, or the soft tissues and removed elements were taken elsewhere for disposal.

\section{Temporal Bone Maldevelopment}

Because the Roffelsen crania were taken out in their matrix as blocks, they could be exposed and cleaned under the more controlled conditions of the laboratory. This allowed for early recognition of a number of defects in their temporal bones, so particular care was taken in the exposure of these elements and the recovery of the auditory ossicles. Unfortunately, the disturbance of E's cranium in the initial testing of Feature 59 and the conditions of D's temporal bones limit the identification of defects in their cases. Also, no observations were possible of G's temporal bones.

The temporal bone flaws occur in the outer and middle ear. Although probably sharing a common etiology, they are quite variable in expression (Table 2). To understand their nature and effect, a brief description of the normal ear is necessary (Lipscomb 1996) (Figure 8). The outer ear consists of the fleshy outer ear (pinna or auricle) and the bony external auditory meatus or canal, which funnels sound from the pinna to the tympanic membrane (eardrum) at its medial end. The anterior and inferior walls of the canal are formed by the tympanic plate. Medial to the tympanic membrane is the tympanic cavity, or middle ear, which 


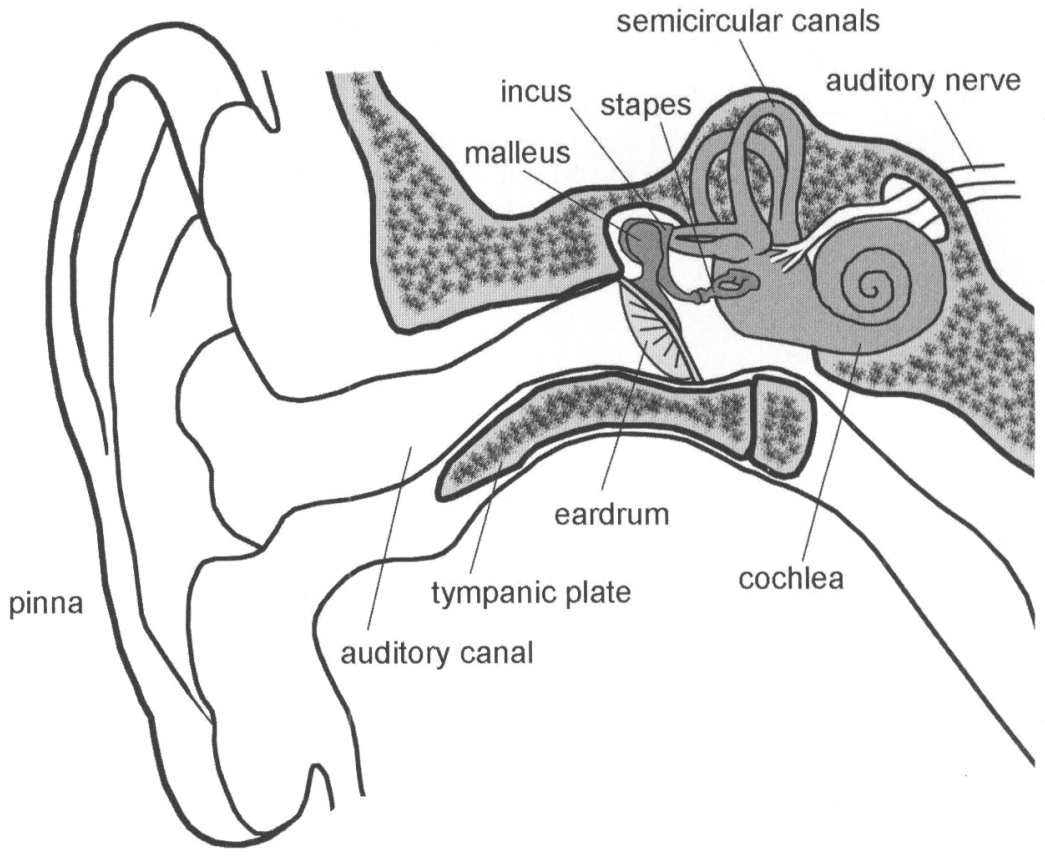

Figure 8. Anterior view of normal right ear.

contains the three ossicles that form the ossicular chain. Lateral to medial, these are the malleus, incus, and stapes. They are mobile and in contact with one another, transmitting the complex pressures from the membrane to the oval and round windows. Medial to the windows is the cochlea, or inner ear, which converts the pressures into the electrical discharges that form the cognitive basis of hearing.

\section{Individual A}

Individual A has defects in the tympanic areas of both temporal bones. The lateral margins of the tympanic plates have a scooped appearance, the plates not having developed laterally to their full extent. The scooped area would normally have been filled by lateral growth of the plate early in childhood (Anderson 1962; Scheuer and Black 2000:80, Figure 5.34). Also, both plates have separate "floating" central segments. These are roughly rectangular, extending most of the length of the plates. On the left side, the segment is 11 by $3 \mathrm{~mm}$. It reaches the scooped lateral edge of the plate, narrowing to leave a gap of $2 \mathrm{~mm}$ in the plate's margin. Both of the longer edges of this segment are in contact with, but not fused to, the remaining anterior and posterior edges of the plate, which themselves had developed properly to join the temporal bone. The malleus and incus are present and normal, but the stapes had never developed.

On the right side, the separate central segment of the tympanic plate is again elongated and roughly rectangular, 12 by $4 \mathrm{~mm}$ (Figures 9-10). It does not reach quite to the scooped lateral margin. The last few millimeters are occupied by extensions of the plate from the anterior and posterior edges, converging but not closing in the middle of the lateral margin. Along its anterior edge the segment contacts, but is not fused with, the remaining anterior strip of plate. Along the segment's posterior edge there is a slight gap between it and the posterior part of the plate. There is no right stapes, but the incus is present and normal. The right malleus is represented only by the malformed head; its manubrium had not developed (Figure 10).

\section{Individual B}

Both tympanic plates of B are normal. Each has a foramen of Huschke, which is normal for B's age and not related to the maldevelopment visible in 


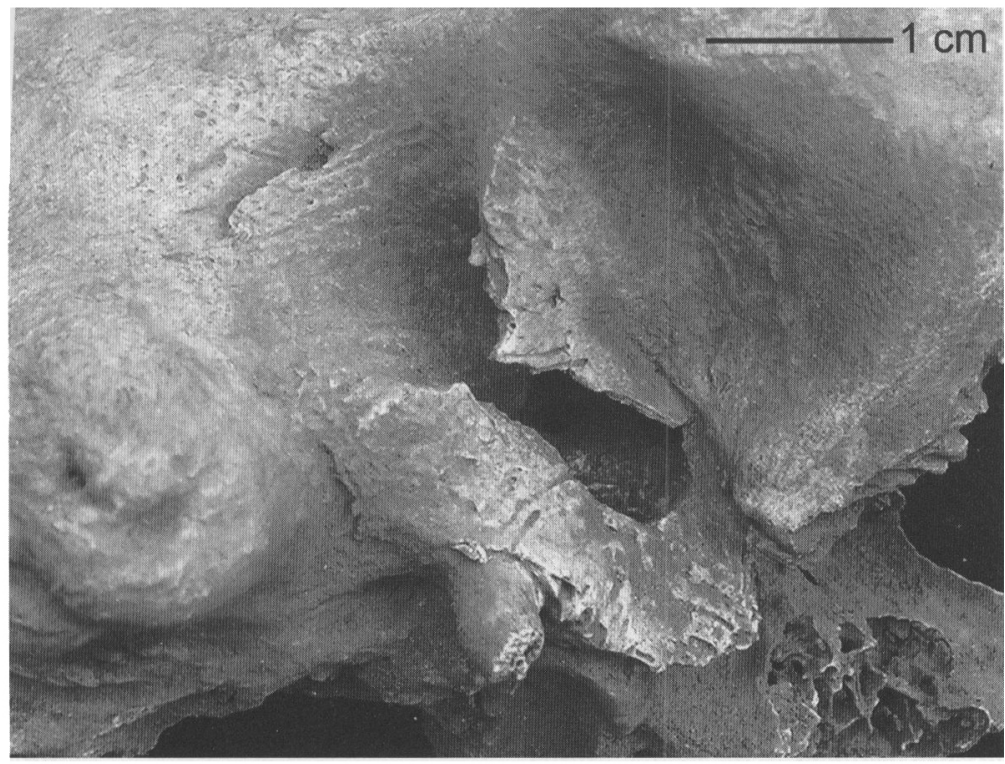

Figure 9. Right temporal bone of individual A showing space for separate central segment of tympanic plate and scooping of lateral border of plate.
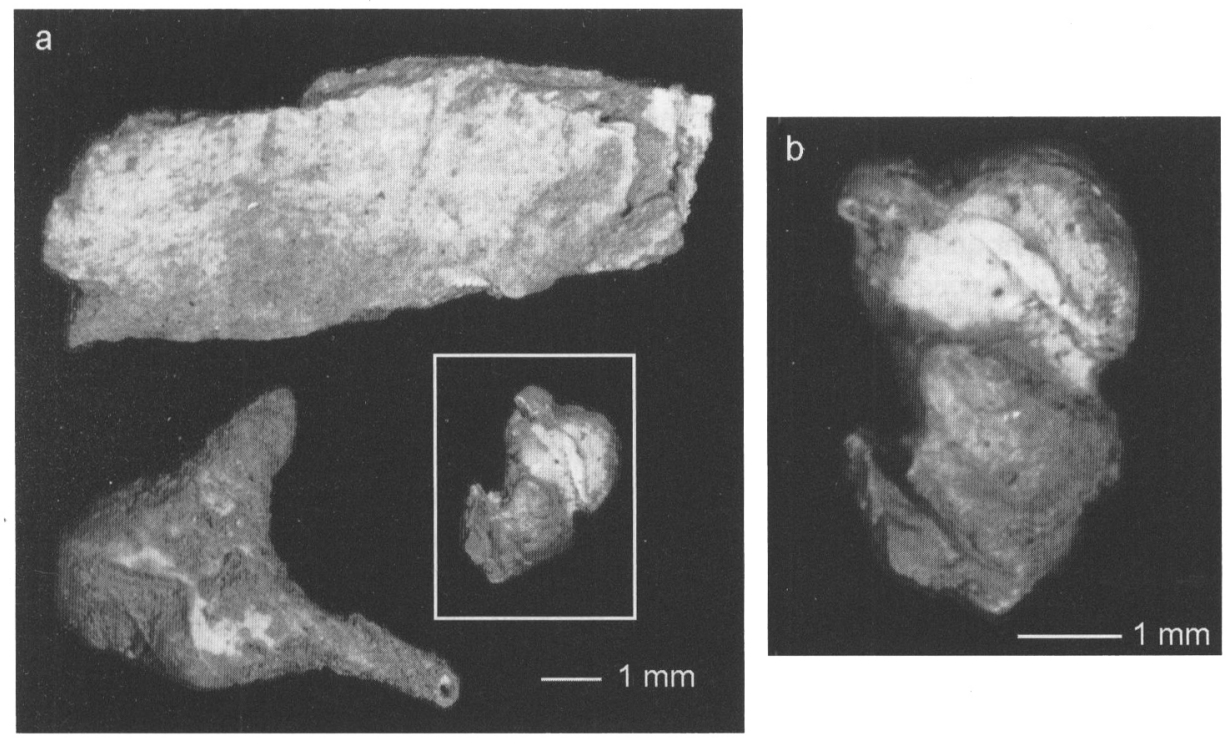

Figure 10. Components of right temporal bone of individual A: (a) separate central segment of plate, normal incus, and deformed malleus: (b) detail of deformed malleus.

the middle ear (Humphrey and Scheuer 2006). However, the right tympanic membrane had calcified, leaving only a small central dehiscence 1 $\mathrm{mm}$ in diameter (see Hodges et al. 1990 for a similar bony occlusion). Also, the right malleus and incus had not formed at all. The stapes is present, but its anterior crus is largely undeveloped. The left malleus and incus are present, but the left stapes had not developed.

\section{Individual $\mathrm{C}$}

There are foramina of Huschke in both tympanic plates. The right plate shows incomplete fusion anteriorly at the petrotympanic fissure. On the left 


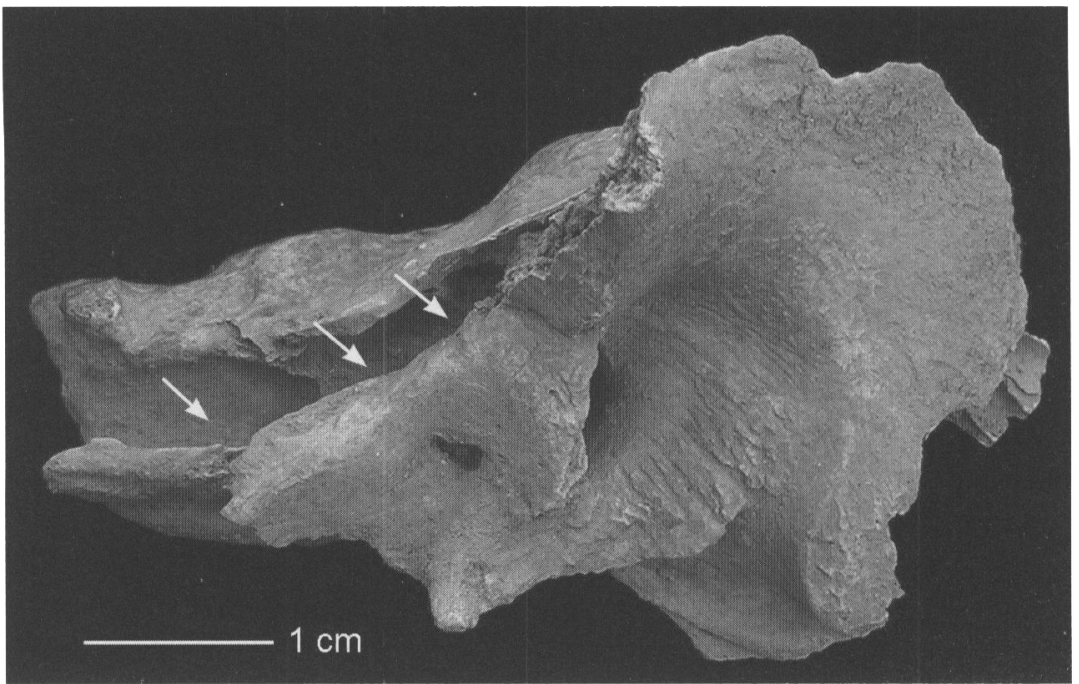

Figure 11. Left temporal bone of individual C. Note gap along petrotympanic fissure, expanding medially to expose anterior side of carotid canal (arrows).

there is a gap in the plate $15 \mathrm{~mm}$ long by $2 \mathrm{~mm}$ wide along the petrotympanic fissure, anterior to the foramen of Huschke (Figure 11). Apparently the anterior arm of the tympanic ring had not developed properly. However, the lateral end of the plate did form fully to join the squamous portion along the squamotympanic fissure. The auditory ossicles are all present and normal on the right side, but none had developed on the left side.

The developmental failure on C's left side extends to the medial part of the petrous portion. The bony antero-lateral surface, which normally would enclose the carotid canal, had not formed (Figure 11). Development of this surface should have been completed in fetal life or shortly after birth (Scheuer and Black 2000: Figure 5.30). The right canal is fully enclosed.

\section{Individual $D$}

There is complete failure of both tympanic plates to develop. None of the ossicles were found. Their absence is probably due to developmental failure, but loss during mortuary processing or decomposition remains a possibility. Neither carotid canal is enclosed on the antero-lateral side.

\section{Individual $E$}

No observations are possible on the right side. The left tympanic plate was represented only by the unfused ring, despite E's age (1.5-1.8 years), and the carotid canal is open antero-laterally. None of the ossicles were present.

\section{Individual F}

There is a small foramen of Huschke on the left side. The left plate has the same deep scoop seen in $\mathrm{A}$, indicating incomplete lateral development. The right plate is also underdeveloped. On both sides, the antero-lateral part of the carotid canal's bony sheath failed to develop. All of the ossicles were recovered except the right stapes.

\section{Individual $G$}

No observations are possible for $\mathrm{G}$ because of displacement of the cranial segments during decomposition, poor preservation of the bone, and the very young age of the infant.

\section{Discussion}

Developmental flaws of the tympanic plate portion of the external auditory canal occur in five of the six observable Roffelsen individuals (Table 2), but it is not clear what effect, if any, these alone would have had on hearing. Their significance lies more in their association with the discontinuities in the ossicular chains of four of the five individuals (seven of nine sides) with observable middle ears (Table 2). This combination of outer and middle ear defects suggests that they are part of a larger complex, some form of congenital au- 
ral atresia: partial or total developmental failure of the external auditory canal, often coupled with ossicular discontinuities (Allanson 2004:111).

Disruptions of the ossicular chain are usually genetic in origin with autosomal dominant inheritance (Gorlin 1995:61; Higashi et al. 1987:659; Mencher et al. 1997:106-108, 117-122). They generally cause a conductive hearing loss in the moderate range, 40-60 dB HL (Gorlin 1995:61; Higashi et al. 1987:656; Park and Choung 2009:419-420; Schuknecht 1993:78; Thomeer et al. 2011). When more than one ossicle is involved, the hearing impairment would be in the upper part of that range or even higher. In the Roffelsen series, A (right ear), B (right ear), C (left ear) and $\mathrm{E}$ (left ear) are in this multiple-defect category. In the case of $\mathrm{B}$, the hearing impairment on the right side would have been compounded by the ossified tympanic membrane.

This is necessarily a conservative assessment of hearing impairment among the Roffelsen people. Although observations were possible of the outer and middle ear, we were unable to assess the inner ear or the conditions of the oval and circular windows. Radiographs were of no use because soil had infiltrated the skeletal elements. Sensorineural hearing impairment, which can be more profound than conductive impairment, is often caused by malformations of the cochlea. The developmental flaws noted in the medial parts of the petrous bones of C (left side), D (both sides), E (left side) and F (both sides) suggest that there may also have been cochlear defects in some of the Roffelsen people.

Hearing impairment is frequently coupled with soft tissue expressions like a disfigured or absent pinna, pigmentation anomalies, and eye variations (Barnes 1994:199, 201; Hodges et al. 1998:80; Mencher et al. 1997:106-107, 125). The presence of these traits might have allowed us to say whether the Roffelsen complex of defects is part of one of the 70 or more genetic syndromes that are associated with conductive hearing loss (Thomeer et al. 2011; Toriello et al. 2004). Unfortunately, these soft tissue expressions cannot be assessed in the Roffelsen series. Also, the Roffelsen defects might fall in either category II or III of Allanson's (2004:111) three types of congenital aural atresia, but since one criterion in their distinction is the form of the pinna, no finer assessment is possible.

\section{Internal Relationships}

Nonmetric traits help to clarify the internal biological (and by extension social) relationships among the Feature 59 people (Hauser and De Stefano 1989). Several traits are shared by two or more individuals (Table 3 ). Individual C (3-4 years) shows complete synostosis of the sagittal suture. This probably has a genetic basis (Barnes 1994:152), hence its inclusion in Table 3, but none of the other Feature 59 individuals exhibit it. The coronal, lambdoidal, and squamosal sutures of $\mathrm{C}$ are normal. Because of disk removal, only the anterior-middle part of the sagittal suture area is visible, but here there is full obliteration of the suture. There is no sagittal ridging, although this might have been present in the missing posterior portion (Cohen 2000:51-52). A prematurely fused sagittal suture causes an elongated cranial vault (scaphocephaly), but generally has no other detrimental effects (David et al. 1982:125-127). Mental impairment is unlikely (Camfield et al. 2000:177). Surgery in modern patients is usually recommended only for cosmetic reasons (David et al. 1982:127-128).

The most unusual nonmetric trait in the series is the location of the mastoid foramen. It is normally found on the temporal or occipital bone or in the masto-occipital suture (Hauser and De Stefano 1989:201-205). However, at Roffelsen it is located on the postero-lateral part of the parietal bone in individuals $B, D$, and $F$. The frequency of parietal location is $3 / 6$ by individual or $4 / 11$ by side. This variant has not been published for any other population (Hauser and De Stefano 1989:201-202).

The nonmetric data, particularly mastoid foramen location, indicate close biological relationships among the Feature 59 people. The temporal bone abnormalities, which probably have a genetic basis, support this. These close biological links presumably reflect close social ties. As the oldest person and the first to be buried, A may have had an ancestral relationship to some or all of the others, while the subadults may have been siblings or cousins to one another. Although the existence of social relationships can often be inferred from biological data, they can rarely be precisely identified in kinship terms (Stojanowski and Schillaci 2006:55). 
Table 3.Non-metric Traits of Individuals from the Roffelsen Site.

\begin{tabular}{|c|c|c|c|c|c|c|c|}
\hline Trait & $\mathrm{A}$ & B & $\mathrm{C}$ & $\begin{array}{c}\text { Individual } \\
\text { D }\end{array}$ & $\mathrm{E}$ & $\mathrm{F}$ & $\mathrm{G}$ \\
\hline Trochlear spur & AR & $\mathrm{AL}$ & PR & & & PR & \\
\hline Access. infraorbital for. & PL, PR & $\mathrm{AL}$ & AR & & & $\mathrm{AL}, \mathrm{AR}$ & \\
\hline Sagittal suture synostosis & A & A & $\mathrm{P}$ & A & A & A & \\
\hline Suprameatal spine & $\mathrm{AL}, \mathrm{AR}$ & PL, PR & $\mathrm{AL}, \mathrm{AR}$ & PR & & $\mathrm{AL}, \mathrm{AR}$ & \\
\hline Asterionic bone & $\mathrm{AL}, \mathrm{PR}$ & $\mathrm{AR}$ & & & & PL, PR & \\
\hline Lambdoidal ossicles & PR & PR & PL & & & PL, PR & \\
\hline Posterior condylar canal & PL, PR & PR & PL, PR & $\mathrm{AL}$ & & PL, AR & PR \\
\hline Mastoid for. on parietal & AL, AR & PL, AR & AL, AR & PL, PR & $\mathrm{AL}, \mathrm{AR}$ & PL & \\
\hline Mastoid for. on temporal & PL, AR & PR & & $\mathrm{AL}, \mathrm{AR}$ & $\mathrm{AL}$ & $\mathrm{AL}$ & \\
\hline Mastoid for. on suture & $\mathrm{AL}, \mathrm{AR}$ & $\mathrm{AL}, \mathrm{AR}$ & & $\mathrm{AL}, \mathrm{AR}$ & & $\mathrm{AL}$ & \\
\hline Mastoid for. on occipital & $\mathrm{AL}, \mathrm{AR}$ & $\mathrm{AL}, \mathrm{AR}$ & AL, AR & AL, AR & & $\mathrm{AL}$ & \\
\hline Access. mental for. & $\mathrm{AL}, \mathrm{AR}$ & PL, AR & AL, AR & & & $\mathrm{AL}, \mathrm{AR}$ & \\
\hline Mylohyoid arch & $\mathrm{AL}, \mathrm{AR}$ & & & & & PL, PR & \\
\hline Atlas divided facet & $\mathrm{AL}, \mathrm{PR}$ & $\mathrm{AL}, \mathrm{AR}$ & $\mathrm{AL}, \mathrm{AR}$ & $\mathrm{AL}$ & & $\mathrm{AL}, \mathrm{AR}$ & $\mathrm{AR}$ \\
\hline Atlas posterior bridge & $\mathrm{AL}, \mathrm{PR}$ & $\mathrm{AL}, \mathrm{AR}$ & $\mathrm{AL}, \mathrm{AR}$ & $\mathrm{AL}, \mathrm{AR}$ & & $\mathrm{AL}, \mathrm{AR}$ & $\mathrm{AR}$ \\
\hline
\end{tabular}

$\mathrm{P}=$ present; $\mathrm{A}=$ absent; $\mathrm{L}=$ left $\mathrm{R}=$ right

\section{The Contributing Community}

Feature 59 was probably the burial facility for a small social unit like an extended family or small lineage. Although some deaths may have occurred simultaneously, it is likely that most or all were consecutive events. Since the burial feature remained unfilled, and most of the soft tissue had been stripped from each corpse, disarticulation through decomposition would not have taken long. Some individuals had apparently been deposited before the articulating soft tissues of the previous burial had decomposed (B after A, C after B). Others displaced and scattered some of the bones of previous individuals, indicating decomposition ( $F$ after $A, E$ after $F$ ).

Crude death rates from two Ontario Iroquoian ossuaries are relevant to a demographic assessment of Roffelsen. Although the ossuaries are slightly later in time than Roffelsen, all three communities were in similar environments and were equally dependent on maize cultivation. The Moatfield Ossuary (A.D. 1280-1320) has a crude death rate of 30.6/1000/year (Merrett 2003:177; see also Speal 2006:18). If the group that contributed to Feature 59 had done so for only a year, this rate would indicate that they numbered about 230 people. It is unlikely that random deaths in a community of that size would include seven such closely related people. At the opposite extreme, a decade of use would suggest a contributing population of only 23 individuals. This is the size of an extended family or small lineage. Archaeolog- ical evidence suggests that the basic settlement unit along the Thames River was probably an extended family (Murphy and Ferris 1990).

However, the use of the facility may have been shorter than a decade and the level of mortality higher. Another relevant crude death rate is $40 / 1000 /$ year for the Uxbridge Ossuary (A.D. 1450-1550) (Pfeiffer 1983:10). This would suggest a shorter use span for Feature 59. Also, the Roffelsen people may have carried some health liabilities that placed them at higher risk than their contemporaries. There may have been some more severe sequelae to the temporal bone maldevelopment (Mencher et al. 1997). The use span of Feature 59, then, may best be placed at 5-10 years, probably by an extended family or small lineage.

\section{Mortuary Treatment}

All individuals were in the extended position (Table 1). The choice between prone and supine was not conditioned by sex; A (supine) and F (prone) were both men. Nor does age seem to have been the main consideration. The oldest (A) was supine, the second oldest (F) prone, and the third and fourth oldest (B and C) supine. Orientation is not determined by age. Although the three oldest individuals (A, B, F) were oriented head to the northwest, so too was one of the youngest $(\mathrm{E})$. The possibility that orientation was based on sex cannot be discounted with the available evidence. All seven individuals had undergone extensive and remarkably consistent mortuary processing. 
The limbs had been stripped of all soft tissue. In the course of this processing, the medial epicondyles of A's and F's humeri were removed. The medial epicondyles were also missing from a burial at the Younge site (Greenman 1937:38). No patellae were found at Roffelsen. For at least A-D, and probably $F$, their removal was part of the processing. Pairs of patellae were present in a few "torso" burials at Younge, probably left in the features after exhumation of the major bones for secondary burial elsewhere (Greenman 1937:35-36).

Scraping and cutting marks on the long bones are concentrated along the diaphyses, dropping off at the metaphyses. Very few occur on the epiphyses. In the case of A, there are lacing holes on the left humerus and ulna because cleaning of the proximal ulna severed connecting tissues. The metacarpals and metatarsals of most individuals have cuts, but their carpals, tarsals, and phalanges do not.

The soft tissues, including the internal organs, were removed from the torso. No fragments of sternum or manubrium were identified. They had probably been removed to allow access to the heart and lungs. At the Younge site, a multiple secondary burial included a perforated manubrium (Greenman 1937:38), so at least in that case there may have been an additional ritual aspect to its removal. The scraping of soft tissue from the back is indicated by cuts on external rib surfaces, some vertebral arches, and the external and internal surfaces of the scapulae. As part of this, the acromion processes and vertebral spines of $A$ and $F$ were cut through and discarded.

The scalp was scraped away, and the other soft tissues of the face and head (including the eyes, ears [if they had developed], tongue, and fleshy part of the nose) were removed. For at least F, excision of the cranial disk had a pragmatic goal, removal of the brain (see Speal 2006:9). Murphy and Ferris (1990:270) and Redmond (1982:24-25) suggest that the disks were retained as ancestral relics. However, few have been found. At the Younge site, disks had been removed from nine crania. Three were found, but, according to Greenman (1937:58), none of these corresponded to the nine removed disks. Two were with "torso burials" (Greenman 1937:35-36) and may have been left when the crania and long bones were exhumed for secondary burial. Both of those burials also in- cluded pairs of patellae. Eleven disks had been removed from Riviere au Vase crania (Fitting 1965:75, Tables 39-40). Only one was found in a burial, but it is not clear whether or not it was originally from that burial (Fitting 1965:Table 40; Redmond 1982:7; Speal 2006:9). At Dymock in Ontario, a disk was present in an otherwise empty grave. Redmond (1982:25) suggests that it was left as a representation of the exhumed individual, but it may simply have been discarded.

At present there is no compelling evidence that the removal of cranial disks from Western Basin burials was for anything more than brain extraction or the release of some spiritual essence in the head. Most of the Roffelsen disks and those found at Bingo Village (Spence 2011) were from subadults who would not yet have fused sagittal and lambdoidal sutures. Those disks would have separated into segments after their removal. Until disks are found buried with individuals from whom they definitely had not been excised or in other contexts that demonstrate their curation, we should not assume that they had any magico-religious or social significance in themselves.

The immediate goal of mortuary processing at Roffelsen was to remove all of the soft tissue from the corpse (see also Raemsch 1993:227-228). However, the epiphyses and the ends of the metaphyses were not stripped, so apparently it was also important to retain an articulated skeleton. The skeletons may have been displayed before burial, fully or partially suspended from the drilled hole near bregma. The area of the second and third lumbar vertebrae was apparently a weak point in the suspended skeleton, requiring the lacing holes seen in A and F. Also, the drilled hole in D's cranium is on the frontal bone, which is thicker and better able to withstand the stress of manufacture and suspension. There is no drilled hole in B's cranium, and probably not in that of E. Age is not the main factor in this distinction. Individual $\mathrm{D}$ is the same age as $\mathrm{E}$ and younger than $\mathrm{B}$. Two Younge site subadults, one 4-6 and the other 7-8 years, also have holes in their frontal bones (Greenman 1937:51-54; Hinsdale and Greenman 1936:5, Plate IV Figure 2). These cranial perforations occur in both sexes in the Michigan sites (Fitting 1965: Table 40; Greenman 1937) but that does not necessarily rule out a role for sex at Roffelsen, given the wide variation in Younge phase 
practices. Of course, if the purpose of the holes was to facilitate suspension, then the question becomes why some skeletons were not suspended, at least not by this particular method.

The consistency of the processing at Roffelsen suggests that a single person, perhaps a shaman with a good understanding of human anatomy, prepared the bodies. Particularly striking parallels are the lacing holes in the second and third lumbar vertebrae and the removal of several bony segments. Also, the same techniques of cutting, scoring, and, finally, pressure or percussion were used to remove the disks.

The mortuary practices observed at Roffelsen were present at other Western Basin sites, although not as such a coherent set. Roffelsen is much more homogeneous, but covers a very limited time span and was probably managed by only one ritual specialist. Single burial features or very small clusters would be the most appropriate comparators.

\section{Conclusions}

The Roffelsen enclosure and burial facility were constructed together. Perhaps the location of Feature 59 on the perimeter of this defined space was meant to reflect the liminal status of these recently deceased people. Many of the burials at the Younge site were located in the wall lines of Enclosure 1 (Greenman 1937:Maps 3,7-8). The construction of the Roffelsen enclosure and burial facility was initiated by the death of $\mathrm{A}$, a man perhaps of some importance in the community. The pit was barely long enough to accommodate A's skeleton, but its width, slightly over a meter, was more than enough for $\mathrm{A}$, whose skeletal width at the shoulders was only $37 \mathrm{~cm}$. That and the fact that the pit was not backfilled after A's burial indicate that it was created with the expectation that further individuals would be interred there.

Van Bemmel, another early Younge phase site in the Chatham area (Ferris 1989), shares one distinctive feature with Roffelsen-a single-row palisaded enclosure 25-30 meters in diameter. Van Bemmel, though, was oriented toward the fall hunting and processing of deer (Ferris 1989). There are no burials at the site, which was probably occupied by only a few families. Perhaps Van Bemmel and Roffelsen represent different points in the same settlement cycle. Ferris (1989:8) sug- gests that the Van Bemmel palisade may have been a windbreak, but palisades may also have had social and symbolic purposes, such as representing a public claim to an area or expressing group identity (Ramsden 1990).

The Roffelsen mortuary homogeneity is probably due to the conduct of mortuary processing by a single shaman. It should not be surprising that each ritual specialist in the region selected his or her particular set of practices out of the broad repertoire available in the Western Basin tradition. The larger Michigan sites probably included the dead of a longer time span and of several different bands. The wide range of practices presented in them is really a palimpsest of the activities of a number of specialists (Speal 2006). These large mortuary sites do not seem to have counterparts among the Younge phase sites in Ontario, where there are few burial features per site, each holding eight people at most, and where there is often associated domestic activity (Dewar et al. 2010; Kidd 1956; Murphy and Ferris 1990; Spence 2011; Watts et al. 2011).

Also, mortuary practices in Ontario vary from site to site, ranging from the defleshed primary burials of Roffelsen to the multiple secondary burials of Bingo Village (Spence 2011). Much of this variability probably reflects the activities of different local shamans, but another factor may have been the sociopolitical independence of the numerous communities across the region. Without the constraints of an overarching political identity, each community was free to express its own particular social truths in its mortuary rituals. Their contemporary Glen Meyer neighbors to the east were similar in this respect (Spence 1994).

Although the Roffelsen burial represents only a sample of the larger social unit (i.e., those who had died), it is likely that a high proportion of the rest of the community had some version of the temporal bone maldevelopment complex, since it appears to follow autosomal dominant inheritance (Higashi et al. 1987:659). One frequent problem of deaf and partially deaf people today is poor oral language development (Mencher et al. 1997:233-237). Moderate hearing loss (40-60 dB HL), like that afflicting the Roffelsen people, leads to problems with both vocabulary and syntax (Roberts et al. 1998:39, 44). These would have been compounded at Roffelsen by other factors. For one, others in the im- 
mediate social environment of individuals $A-G$ were probably experiencing similar hearing and language difficulties and so unable to assist the language development of their kin. Also, language difficulties are exacerbated when the hearing loss is present from birth, before language has even started to develop (Eisenberg et al. 2012:256). In a small community where many of the people suffered some hearing deficit, and contact with outsiders may have been limited to certain parts of the settlement cycle, it is possible that only a few members of the group would have been capable of fully effective oral communication. Furthermore, a number of them may have had some of the visible stigmata that often accompany genetically based deafness: malformed or unformed external ears, bulging eyes, pigmentation anomalies, and so forth (Barnes 1994:199, 201; Hodges et al. 1990; Mencher et al. 1997:106-107, 122-128).

The Roffelsen people, then, may have experienced some degree of social isolation. It is doubtful that this would have been complete. The Onondaga chert piece from the burial, for example, has a rough cortex surface that indicates its origin in the primary deposits well to the east. Some marriage exchange would also be expected. Despite this, it seems likely that the people of the Roffelsen extended family had more limited external social relationships than other similar groups of the time. This may not have had a serious impact on the group's survival in the short term. The limited period of site use, though, suggests that the group did not persist long as an independent social unit. We may be able to learn more about their relationships with neighboring groups and their ultimate fate by tracing the distribution of their distinctive physical features in other skeletal series of southwestern Ontario.

Acknowledgments. We are very grateful to Henry and Lisa Roffelsen for their generous support of the excavation and analysis of this important site. Their interest in these ancient people provided a constant stimulus for our work. We also thank Jim Wilson, director of Archaeologix Inc., for the opportunity to work on the site, and Adria Grant and Tracie Carmichael for their patient and careful work in the excavation. Christine D. White kindly conducted isotopic analyses of some skeletal elements, and Lisa Hodgetts identified the material of the bone implement. The comments of Christopher Watts and three other reviewers led to considerable improvements in the article. However, particular thanks go to David White and the people of Bkejwanong First Nation (Walpole Island), who gave permission for the work and who have expressed a deep interest in the stories that their ancestors have to tell them.

\section{References Cited}

Allanson, Judith

2004 Genetic Hearing Loss Associated with External Ear Abnormalities. In Hereditary Hearing Loss and Its Syndromes, edited by Helga V. Toriello, William Reardon, and Robert J. Gorlin, pp. 83-125. 2nd ed. Oxford Monographs on Medical Genetics No. 50. Oxford University Press, Oxford.

Anderson, James E.

1962 The Development of the Tympanic Plate. National Museum of Canada Bulletin 180:143-153.

Archaeologix Inc.

2006 The Roffelsen Site (AcHn-33), AcHn-32 and AcHn34, South Half of Lot 16, Concession 1, Township of Dover, County of Kent, Ontario. Report on file, Ontario Ministry of Tourism, Culture and Sport, Toronto.

Barnes, Ethne

1994 Developmental Defects of the Axial Skeleton in Paleopathology. University Press of Colorado, Niwot.

Braun, Mark, Della Collins Cook, and Susan Pfeiffer

1998 DNA from Mycobacterium tuberculosis Complex in North American, Pre-Columbian Human Skeletal Remains. Journal of Archaeological Science 25:271-277.

Brickley, Megan, and Rachel Ives

2006 Skeletal Manifestations of Infantile Scurvy. American Journal of Physical Anthropology 129:163-172.

Camfield, Peter R., Carol S. Camfield, and M. Michael Cohen, Jr. 2000 Neurologic Aspects of Craniosynostosis. In Craniosynostosis: Diagnosis, Evaluation, and Management, edited by M. Michael Cohen, Jr., and Ruth E. MacLean, pp. 177-183. 2nd ed. Oxford University Press, Oxford.

Cohen, M. Michael, Jr.

2000 Sutural Pathology. In Craniosynostosis: Diagnosis, Evaluation, and Management, edited by M. Michael Cohen, Jr., and Ruth E. MacLean, pp. 51-68. $2^{\text {nd }}$ ed. Oxford University Press, Oxford.

David, John, David Poswillo, and Donald Simpson 1982 The Craniosynostoses. Springer-Verlag, Berlin.

Dewar, G., J.K. Ginter, B.A.S. Shook, N. Ferris, and H. Henderson 2010 A Bioarchaeological Study of a Western Basin Tradition Cemetery on the Detroit River. Journal of Archaeological Science 37:2245-2254.

Eisenberg, Laurie S., Karen C. Johnson, Sophie E. Ambrose, and Amy S. Martinez

2012 Atypical Auditory Development and Effects of Experience. In Human Auditory Development, edited by Lynne Werner, Richard R. Fay, and Anthony N. Popper, pp. 255-277. Springer Handbook of Auditory Research Vol. 42. Springer, New York.

Ferris, Neal

1989 A Preliminary Report on the 1987-1988 London Chapter Excavations at the Van Bemmel site, Kent County, Ontario. Kewa 89(6):2-22.

Fitting, James

1965 Late Woodland Cultures of Southeastern Michigan. Anthropological Papers No. 24. Museum of Anthropology, University of Michigan, Ann Arbor.

Gorlin, Robert J.

1995 Genetic Hearing Loss with No Associated Abnormalities. In Hereditary Hearing Loss and its Syndromes, edited by Robert J. Gorlin, Helga V. Toriello, and M. Michael Cohen, Jr., pp. 43-61. Oxford Monographs on Medical Genetics No. 28. Oxford University Press, Oxford.

Greenman, Emerson

1937 The Younge Site: An Archaeological Record from Michigan. Occasional Contributions No. 6. Museum of Anthropology, University of Michigan, Ann Arbor. 
Hauser, G., and G. De Stefano

1989 Epigenetic Variants of the Human Skull. E. Schweizerbart'sche Verlagsbuchhandlung, Stuttgart.

Higashi, Koichiro, Koji Yamakawa, Osamu Itani, and Kiyoshi Togawa

1987 Familial Ossicular Malformations: Case Report and Review of Literature. American Journal of Medical Genetics 28:655-659.

Hinsdale, W., and Emerson Greenman

1936 Perforated Indian Crania in Michigan. Occasional Contributions No. 5. Museum of Anthropology, University of Michigan, Ann Arbor.

Hodges, Denise, Lee Harker, and Shirley Schermer

1990 Atresia of the External Acoustic Meatus in Prehistoric Populations. American Journal of Physical Anthropology 83:77-81.

Humphrey, L. T., and L. Scheuer

2006 Age of Closure of the Foramen of Huschke: An Osteological Study. International Journal of Osteoarchaeology 16:47-60.

Kidd, Kenneth

1956 A Brief Study of the Human Remains from the Krieger Site in Southwestern Ontario. Pennsylvania Archaeologist 26:15-26.

Lipscomb, David L.

1996 The External and Middle Ear. In Hearing Disorders, edited by Jerry L. Northern, pp. 1-13. 2nd ed. Allyn and Bacon, Boston.

Mencher, George, Sanford Gerber, and Andrew McCombe

1997 Audiology and Auditory Dysfunction. Allyn and Bacon, Toronto, Ontario.

Merrett, Deborah

2003 Moatfield Demography. In Bones of the Ancestors: The Archaeology and Osteobiography of the Moatfield Ossuary, edited by Ronald Williamson and Susan Pfeiffer, pp. 171-187. Archaeology Paper No. 163. Canadian Museum of Civilization, Hull, Quebec.

Moorrees, Conrad, E. Fanning, and E. Hunt

1963a Formation and Resorption of Three Deciduous Teeth in Children. American Journal of Physical Anthropology 21:205-213.

1963b Age Variation of Formation Stages for Ten Permanent Teeth. Journal of Dental Research 42:1490-1502.

Murphy, Carl, and Neal Ferris

1990 The Late Woodland Western Basin Tradition of Southwestern Ontario. In The Archaeology of Southern Ontario to A.D. 1650, edited by Christopher Ellis and Neal Ferris, pp. 189-278. Occasional Publication No. 5. Ontario Archaeological Society London Chapter, London, Ontario.

Ortner, Donald, and Walter Putschar

1985 Identification of Pathological Conditions in Human Skeletal Remains. Smithsonian Institution Press, Washington, D.C.

Park, Keehyun, and Yun-Hoon Choung

2009 Isolated Congenital Ossicular Anomalies. Acta OtoLaryngologica 129:419-422.

Pfeiffer, Susan

1983 Demographic Parameters of the Uxbridge Ossuary Population. Ontario Archaeology 40:9-14.

Pfeiffer, Susan, and Scott I. Fairgrieve

1994 Evidence from Ossuaries: The Effect of Contact on the Health of Iroquoians. In In the Wake of Contact: Biological Responses to Conquest, edited by Clark Spencer Larsen and George R. Milner, pp. 47-61. Wiley-Liss, San Francisco.

Phenice, T. W.

1969 Newly Developed Visual Method of Sexing the Os Pubis. American Journal of Physical Anthropology 30:297-302.
Raemsch, Carol

1993 Mechanical Procedures Involved in Bone Dismemberment and Defleshing in Prehistoric Michigan. Midcontinental Journal of Archaeology 18:217-244.

Ramsden, Peter

1990 Death in Winter: Changing Symbolic Patterns in Southern Ontario Prehistory. Anthropologica 32:167-181.

Redmond, Brian

1982 Drilled Skulls and Eyes of Clay: Late Woodland Burial Ceremonialism in the Western Lake Erie Basin. Tole do Area Aboriginal Research Bulletin 11:1-36.

Roberts, Joanne E., Ina F. Wallace, and Diane Brackett 1998 Development of Speech and Language. In Pediatric Otology and Neurotology, edited by Anil K. Lalwani and Kenneth M. Grundfast, pp. 39-47. Lippincott-Raven, New York.

Scheuer, Louise, and Sue Black

2000 Developmental Juvenile Osteology. Academic Press, New York.

Schuknecht, Harold F.

1993 Pathology of the Ear. 2nd ed. Lea and Febiger, Philadelphia, Pennsylvannia.

Speal, C. Scott

2006 The Social Implications of Younge Complex Mortuary Ritual: A Survey of Post-Mortem Skeletal Modifications from Riviere Au Vase, Michigan. Archaeology of Eastern North America 34:1-28.

Spence, Michael W.

1994 Mortuary Programmes of the Early Ontario Iroquoians. Ontario Archaeology 58:6-20.

2011 The Bingo Pit Mortuary Features: Technical Report. Brandy E. George Cultural Research Inc., Kettle and Stony Point First Nation, Ontario. Copies available from Department of Anthropology, University of Western Ontario, London, Ontario.

Spence, Michael W., Christine D. White, Neal Ferris, and Fred J. Longstaffe

2010 Treponemal Infection in a Western Basin Community. Kewa 10(8): 1-10.

Spence, Michael W., Lana Williams, and Sandra Wheeler

2007 The Roffelsen Site Burials. Archaeologix Inc., London, Ontario. Copies available from Department of Anthropology, University of Western Ontario, London, Ontario.

Stojanowski, Christopher, and Michael Schillaci

2006 Phenotypic Approaches for Understanding Patterns of Intracemetery Biological Variation. Yearbook of Physical Anthropology 49:49-88.

Suchey, Judy, and Daryl Katz

1998 Applications of Pubic Age Determination in a Forensic Setting. In Forensic Osteology, edited by Kathleen Reichs, pp. 204-236. 2nd ed. Charles C. Thomas, Springfield.

Thomeer, Henricus G. X. M., Henricus P. M. Kunst, and Cor W. R. J. Cremers

2011 Congenital Stapes Ankylosis Associated with another Ossicular Chain Anomaly. Archives of Otolaryngology Head and Neck Surgery 137:935-941.

Toriello, Helga V., William Reardon, and Robert J.Gorlin (editors) 2004 Hereditary Hearing Loss and its Syndromes. 2nd ed. Oxford Monographs on Medical Genetics No. 50. Oxford University Press, Oxford.

Watts, Christopher M., Christine D. White, and Fred J. Longstaffe 2011 Childhood Diet and Western Basin Tradition Foodways at the Krieger Site, Southwestern Ontario, Canada. American Antiquity 76:446-472.

Submitted March 12, 2013; Revised June 8, 2013; Accepted July 27, 2013. 


\section{NEW FROM THE STATE HISTORICAL SOCIETY OF NORTH DAKOTA}
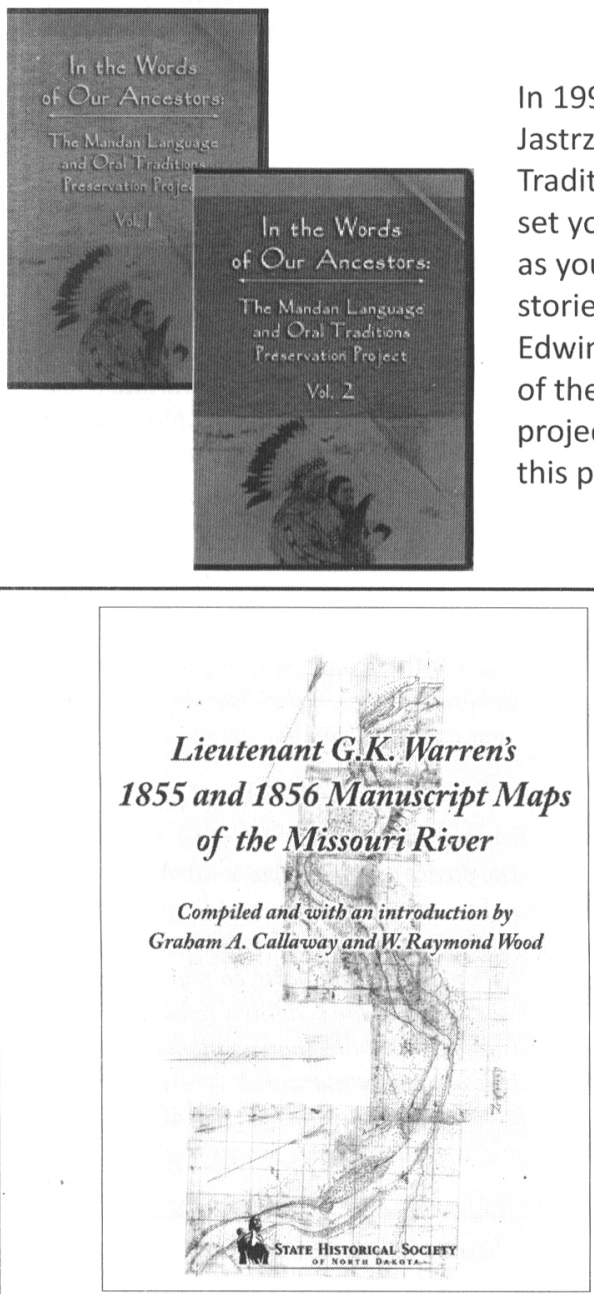

For the first time since they were created more than 150 years ago, a series of maps of the Missouri River is available to the public.

\section{Lieutenant G.K. Warren's 1855 and 1856}

Manuscript Maps of the Missouri River is a portfolio that includes 39 maps (16"x24") of the river from what is now the KansasNebraska border to the confluence of the Missouri and Yellowstone rivers.

\section{$\$ 39.95$}

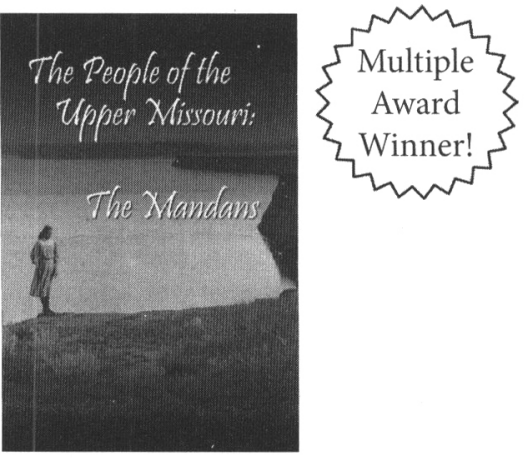

Focusing on the history, traditions, and material culture of the Mandan people, the documentary focuses on the history, traditions, and material culture of the Mandan people, tracing 800 years of Mandan resilience, adaptability, and continuity in the Upper Missouri River Valley. It begins with a contemporary portrait of the Mandan, Hidatsa, and Arikara people and travels backward in time. 77 minutes.

\section{\$24.94 - DVD or BlueRay}

STATE

HISTORICAL SOCIETY

OF NORTH DAKOTA
Museum Store in the North Dakota Heritage Center on the State Capital Grounds, Bismarck

701.328.2822 or email museumstore@nd.gov www.history.nd.gov/museumstore 